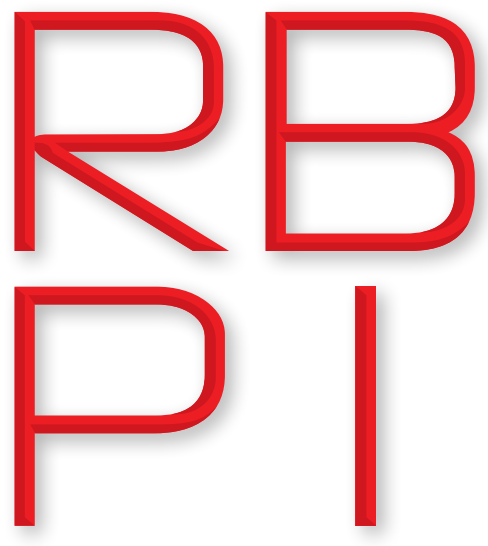

Revista Brasileira de Política Internacional ISSN 1983-3121

http://www.scielo.br/rbpi

\section{Luiza Rodrigues Mateo ${ }^{1}$}

'Pontifícia Universidade Católica de São Paulo, Relações Internacionais, São Paulo, SP, Brazil (luizamateo@hotmail.com).

iD ORCID ID: orcid.org/0000-0002-1945-9853

\section{Copyright:}

- This is an open-access article distributed under the terms of a Creative Commons Attribution License, which permits unrestricted use, distribution, and reproduction in any medium, provided that the original author and source are credited.

- Este é um artigo publicado em acesso aberto e distribuído sob os termos da Licença de Atribuição Creative Commons, que permite uso irrestrito, distribuição e reprodução em qualquer meio, desde que o autor e a fonte originais sejam creditados.

\title{
The changing nature and architecture of U.S. democracy assistance
}

DOI: http://dx.doi.org/10.1590/0034-7329202000110

Rev. Bras. Polít. Int., 63(1): e010, 2020

\begin{abstract}
Democracy assistance is an important tool of United States foreign policy, serving strategic interests in association with several agendas, from human rights to national security. The objective of this article is to make a historical reconstruction of the definitions and practices of American democracy assistance, describing its institutional architecture, budgetary levels and political priorities. Special attention is given to U.S. foreign aid rationale and contemporary trends, recapturing the last thirty years of growth in democracy assistance since the end of the Cold War.
\end{abstract}

Keywords: Democracy promotion; Democracy assistance; Foreign policy; Foreign aid; United States.

Received: January 22, 2020

Accepted: July 6, 2020

\section{Introduction}

$\mathrm{D}$ emocracy promotion can be understood both as a striking feature of United States foreign policy and as one of its greatest contradictions. Democracy is a core element of "Americaness," and it informs a shared understanding of U.S. role in the world, in a sense of mission that translates a foreign policy tasked with "bringing freedom" abroad. At times, leaders thought that democracy export would take place on the strength of example; at other times, it was defended with the use of force. It was generally associated, as a complement or justification, to other domestic interests and ambitions in the international system. Therefore, it came to be undeniably associated with other (assumed universal) values, such as human rights, and other processes, such as the defense of free trade. More than just an ideational drive, democracy promotion also served to American core-interests, defined by the "security and prosperity" linkage, combining soft and hard tools to push and punish foreign countries, and to build 
a stable international order. In this sense, it is an intrinsic part of the American hegemonic liberal order consolidated since the mid-twentieth century.

The purpose of this article is to explore why and how the U.S. undertakes democracy assistance, through an exploratory review of specialized literature. Primarily, it seeks to historically assess the importance of democracy aid in U.S. foreign policy, understanding how it has evolved - in its nature and rhetorical guise - while meeting the strategic demands Washington has faced in recent decades. The main argument is that democracy assistance responded to the same pattern as American foreign aid. It responded to large transformations in foreign policy strategy in three distinct phases: the Cold War, the post-Cold War period and post-9/11. In analyzing recent trends, the article tries to contribute to the debate whether the Trump administration's attempt to dramatically reduce American foreign assistance may represent a major change in the historically growing commitment to democracy aid.

Furthermore, we discuss how democracy assistance is structured in terms of bureaucratic design, as well as its main strategic objectives and recent trends since its consolidation, after the end of the Cold War. In the wake of debates on foreign aid and development assistance, the expansion of the aid agenda from an economic-centered approach to a multidimensional one (including political-institutional and societal elements), in which assistance for "democratic governance" gave rise to a series of programs and projects in the field of electoral support, rule of law and basic rights and freedoms. Within the security agenda, democracy promotion was closely associated with the construction of stability and international order, both during the fight against communism and global terrorism.

In practice, the democratic agenda appears to have a diffuse character. This is mainly due to the fragmented nature of foreign aid, which occurs both bilaterally and multilaterally. It also stems from the "division of labor" in the American bureaucracy - centered around, but not exclusive to the United States Agency for International Development (USAID) - in addition to the broad participation of for-profit and non-profit organizations in the implementation phase of programs and projects. The hybrid (public-private) element of democracy assistance makes it a powerful tool, able to reach not only partner countries, but also those where American aid is not welcome, operating in complex civil society networks in dozens of countries around the world.

\section{Democracy assistance and U.S. foreign policy: support, framing and historical trends}

United States' democracy promotion has been part of the foreign policy agenda and practice for at least a century. Its ideational foundations lie in American exceptionalism, that is, the notion that the U.S. is a unique country in the world, a singular experiment defined as republican and democratic, involving reverence for the founding fathers and the constitution itself. The "civil religion" creates the idea of a "city upon a hill" in which Americans perceive themselves as an 
example for the rest of the world to follow. Democracy has been considered an element of foreign policy since the first phase of American expansion at the end of the nineteenth century.

It accompanied the projection of economic interests and military power to the Pacific (following the Philippines War) and to Central America and the Caribbean (following the Spanish-American War) - interventions justified as part of the liberation struggle against Spanish rule. To some extent, the Cuban experience, with the unfolding of the "splendid little war" of 1898, sparked an internal debate that proved to be decisive for consolidating the limits of U.S. foreign policy in the next century. Despite the real possibility of annexing the island, congressmen decided to support Cuban self-rule, even if it meant a period of tutelage, made possible by the so-called Platt Amendment.

It was during the first quarter of the twentieth century, notably during the Woodrow Wilson administration, that democracy began to be discussed not only as a desirable set of principles and political regime, but as a necessary element of stability on the global stage. Wilson described America's entry into the First World War as an effort "to make the world safe for democracy." Wilson's liberal internationalism framed democratic values as a pillar of the post-World War I order. The preservation of peace would depend more on building international institutions, the rule of law, freedom of public opinion and trade, than on power politics with alliances and armaments (Bridoux 2013, 235).

Wilsonian liberalism also introduced democracy as a justification for external interventions: "When President Woodrow Wilson ordered the occupation of Veracruz, Mexico, in 1914, the intervention in Haiti in 1915, and the takeover of the Dominican Republic in 1916, he justified his actions as part of an effort to bring constitutional democracy to Latin America" (Smith 2012, 5). The period marked an inflexion in U.S. democracy promotion, from a passive exemplarism strategy that considers democracy a worthy goal itself, to an active defense of democracy as a precondition or an instrument to foster American safety and prosperity at home - a necessary foreign policy crusade (Poppe 2010, 5-6).

At the end of World War II, the U.S. became directly involved in democratization projects abroad, notably in the reconstruction of Germany and Japan, supported politically and economically by Washington. From Franklin D. Roosevelt's four freedoms to Truman's defense of the Marshall Plan, the U.S. reaffirmed a commitment to global democracy consolidation, as an expression of American values. As a Cold War expedient, however, containment provided the operational logic that conditioned Washington decisions. With "the advent of the Cold War did a foreign policy agenda emerge that preferred stability over values and the fight of communism over the promotion of democracy" (Huber 2015, 51).

During the Lyndon Johnson, Richard Nixon and Gerald Ford administrations, the expressed diplomatic, economic and military support for non-democratic (or expressly autocratic) regimes gave rise to the expression "friendly dictators." In Latin America, for instance, democracy promotion was linked to the militaristic drive to support regime change (either openly or through covert operations), with examples such as Guatemala (1954), Cuba (1961), the Dominican Republic (1965), Chile (1970-73), Nicaragua (1982-89), and El Salvador (1980-89) (Scott and Carter 2015, 9). 
In the 1970s, the Jimmy Carter administration revived the value of democracy as a foreign policy principle, placing democracy promotion as an element of the human rights agenda, especially in Latin America. It is worth highlighting how the entire logic of U.S. foreign aid was conditioned to the formal disapproval of governments that violated human rights, through negative conditionalities, such as denying military aid to various repressive regimes in the region (Lawson and Epstein 2019, 4). However, it was during the resumption of the Cold War, under the Ronald Reagan administration, that democracy promotion gained another important element, this time not associated with human rights, but with national security itself.

A formal strategic logic indicated the need to support democracy, in its formalist aspect, to assure the defeat of communism. The Reagan years marked the "shift of democracy promotion to combat mode with the maximal expansion of liberal democracy and free-market economy to counter communist advances" (Bridoux 2013, 236). The institutionalization of democracy assistance marked a tactic move, from indirect methods of exporting democracy to "direct aid to political parties and civil society groups to create functioning democratic systems overseas" (Pee 2018, 694).

It is clear that Washington's support for democratic transitions in the 1980s was related to the will to reconfigure arrangements of power favorable not only to U.S. geopolitical interests, but also to geo-economic ones, as capitalism itself entered a new phase of expansion. According to Robinson, this change took place with the new structure of globalization, with the advance of the transnational impetus of productive and financial capital: "the shift to promoting polyarchy corresponds to the emergence of the global economy since the 1970s" $(2000,311)$.

In using the term polyarchy, the author refers to a minimalist and procedural conception of democracy, which in this context would be better able to serve the interests of the political and economic elites - integrated into the transnational circuits of neoliberal capitalism - than the repressive models prevailing in dictatorships of previous decades. Robinson states that democracy promotion is focused on empowering "transnationally oriented elites who are favorably disposed to open up their countries to free trade and transnational corporate investment" (2013, 229), while simultaneously containing "counter-elites" not interested in neoliberal project or mass politization.

Thus, even while the Reagan government continued to endorse "friendly dictators," it began in practice to support political transitions. This is because "Counter-insurgency warfare and support to friendly forces were of decreasing utility and were causing embarrassment to the administration" (Bridoux 2013, 237). The change in tone was accompanied by the creation of the National Endowment for Democracy (NED) in 1983, allowing the expansion of democracy assistance, through funding of non-governmental organizations and specific civil society movements.

Between 1974 and 1990, at least thirty countries transitioned to democracy, in what Huntington (1991) called the "third democratic wave." That included Latin America and Asia during the 1980s, and from 1989 onward, Eastern Europe and sub-Saharan Africa, where many countries were assisted by U.S. democracy programs, financing and providing technical assistance to elections, as well as party and media training, judicial reforms, and projects directed at civil society organizations (Lancaster 2007, 48). In some cases, the promotion of democracy clearly 
served as a formal justification for a series of interventions carried out mainly in Central America in this period (El Salvador, Nicaragua, Panama). The persistent relationship between the defense of democratic principles, strategic interests and military interference is one of the great paradoxes of American democracy promotion since the 1980s (Mitchell 2016).

In the post-Cold War scenario, foreign aid for democratic transitions became especially relevant. Until the 1990s, democracy assistance was a byproduct of other programs or a secondary goal of American foreign aid, losing only in magnitude to humanitarian assistance. Since then, democracy assistance budgets expanded abruptly and encompassed a diverse portfolio of American foreign aid, from electoral support to institutional building and good governance (Seligson et al. 2008, 150). Democracy assistance programs, mainly those conducted by USAID, gained ground vis-à-vis broader democracy promotion tools - which includes political and diplomatic measures to induce and strengthen the democratic norm, from economic sanctions to military interventions.

According to Cox et al., to some extent "democracy promotion has rather neatly filled the missionary gap left behind by the collapse of international communism" $(2000$, 5). It can be described as both an attempt to reconnect foreign policy with American "fundamental principles," and to respond to the strategic vacuum left by the end of bipolarity. It also matched the triumphalist climate after the Cold War, pointing to the "end of history," with the victory of the liberal paradigm, and the unipolar moment that led the U.S. to project itself into the reshaping of the "new international order."

This was the case for the George H. W. Bush administration, which acted promptly to assist democratization in Poland and Hungary, and supported transitions after the end of Soviet Union in 1991, including Russia. By 1994, democracy promotion reached US\$2,5 billion for twenty-six countries in Eastern Europe and the former URSS (Lancaster 2007, 83). Support for democratic transition extended from the White House to Capitol Hill, with the approval of the East European Democracy Act (1989) and the Freedom Support Act (1992), which created new accounts for democracy assistance. Democracy aid was also directed at sub-Saharan Africa, in order to finance elections, strengthen the rule of law, support civil society and improve governance.

Academic debates about the likelihood that "democracies will not go to war with each other" regained momentum in the 90s. Doyle's work best represented the Kantian revival in defense of "liberal peace" based on republican representation, cosmopolitan law, and economic interdependence. For the scholar, the liberal rule and democracy promotion would improve the states' self-restraint and cooperation, necessary to the expansion of a zone of peace (Doyle 1986, 1156). Studies on the peace-proneness of democracies paralleled "democratic peace" defense in Washington's own strategic framing, mainly during the Bill Clinton administration.

In the 1994 State of the Union Address, Clinton put that active defense of democracy and human rights should figure as the government's third strategic pillar, together with security and economic prosperity. American leadership in the new global context depended on this tripod, as stated at the passage of the National Security Strategy for a New Century: 
Underpinning that international leadership is the power of our democratic ideals and values. In designing our strategy, we recognize that the spread of democracy supports American values and enhances both our security and prosperity. Democratic governments are more likely to cooperate with each other against common threats and to encourage free and open trade and economic development - and less likely to wage war or abuse the rights of their people. Hence, the trend toward democracy and free markets throughout the world advances American interests. The United States must support this trend by remaining actively engaged in the world. This is the strategy to take us into the next century (National Security Strategy 1997).

The concept of "engagement and enlargement" was central to the Clinton Doctrine, which tried to forge a new foreign policy consensus in terms of an active defense of "market democracy" as a model of success, combining the political and economic aspects as complementary and mutually reinforcing. In a discourse analysis of the Clinton administration, Poppe $(2010,11)$ claims that its "pragmatic neo-Wilsonian" approach put democracy promotion in relation both to national identity and the construction of a (all positive) liberal order, as to the U.S.' own interests (national security and economy). If democracy promotion was stressed in rhetoric, the use of force to promote it was remotely considered, and democracy assistance was directed at countries already in the course of democratization in Latin America and Eastern Europe. Some bureaucratic reforms gave birth to permanent democracy programs in the early 1990s, pioneered by human rights and development officials. For USAID and the State Department, it was clear that political corruption, mismanagement and repression would hinder economic and social progress (Lancaster 2007, 84).

Allison and Beschel $(1992,90)$ define democracy promotion as a three-way path: creation of an external environment favoring democracy, support for democratic infrastructure within states, and specific strategies for democratizing individual states. Foreign assistance initiatives prescribed by the authors could play a significant role in the consolidation of free market democracies, in accordance with U.S. interests. In fact, democratic rule was a central aspect of American liberal order built since 1945 , described by Ikenberry $(2011,36)$ as “open and loosely rule-based.” Even in apparent contradiction with the continued use of force, democratic promotion played a central role in the U.S.' liberal grand strategy during and after the Cold War, in an expansion of identity marks, capitalist market, international institutions and governance mechanisms that gave U.S. leadership legitimacy, in a consolidating moment for liberal rule inside states and between them.

\section{Recent developments: rise and fall of U.S. democracy assistance}

Democracy promotion gained even more strength with the changes in U.S. foreign policy after the 9/11 terrorist attacks. During the George W. Bush administration, democracy promotion appeared both as an end in itself and as a mean to other ends, notably to national security. As Poppe $(2010,15-16)$ noted, it also helped to rebuild a dichotomic rhetoric of a world divided 
between freedom and tyranny. Thus, America's mission to fight communism was reedited in terms of the global war on terror. Bridoux points out that the Bush administration "made strong rhetorical commitments to democracy promotion as a security response to 9/11 that, eventually, translated in practice into the Freedom Agenda: freedom and democracy are eternally right and their global expansion a guarantee of US security" (2013, 238).

The broad association between the threat of transnational terrorism and the deficit in economic and institutional development has led to the reaffirmation of a security-development nexus, and what can be understood as a deepening in "foreign aid securitization" (Brown and Gravingholt 2016). In fact, not only terrorism, but also other transnational security threats - such as organized crime, environmental and refugee crises, the spread of pandemics, among others - were posed by American strategy as a result of state fragility and blind spots in democratic governance (Mateo 2017, 65-66). In this sense, minimal functioning of institutions, the rule of law and civil stability in fragile states were framed as security concerns. The answer would come in the form of "external corrections" through a mosaic of aid programs: "[...] The discussion involving the promotion of democracy seems to gain a technical dimension: democratic institutions allow countries to perform not only more justly, but also efficiently the tasks considered essential for each state, such as providing security and other public goods" (Gomes 2016, 7).

Therefore, "the George W. Bush Administration asserted that lack of democracy in the Arab world created a breeding ground for terrorism, and that democracy promotion could help contain Islamist extremism as it once had sought to contain Marxist rebels" (Lawson and Epstein 2019, 6). In an interesting discursive analysis covering the Bill Clinton and George W. Bush administrations, Santos (2010) identifies continuity of rhetorical elements in American strategic logic: the universality of democratic values (which accentuates the sense of mission of foreign policy), its relationship with world peace and promotion of American security and prosperity.

Once again, Congressional support helped to invigorate foreign aid agenda, directly or indirectly related to the promotion of democracy. This was shown in the approval of the Middle East Partnership Initiative (2003) and in the creation of the Millennium Challenge Corporation (2004). These measures clearly increased pressure for reforms in the name of building the "good governance" valued by USAID. Then Secretary of State Condoleezza Rice highlighted the role of democracy promotion projects in what she called "transformational diplomacy" that should guide foreign policy towards comprehensive advances in partner countries, including political and institutional consolidation. After the 2006 reforms in the foreign aid system, the "governing justly and democratically" axis was defined as one of the strategic pillars of diplomacy and development cooperation.

What stands out in post-9/11 foreign policy, however, is the interconnectedness between democracy assistance and the largest U.S. military interventions in the $21^{\text {st }}$ century. These included the reconstruction projects in Afghanistan and Iraq, which catalyzed much of the growing foreign assistance resources, especially since 2004 , when the total aid volume rose from US\$16 billion to US\$50 billion. In this context, Middle East and Asia became priority regions in American 
democracy promotion. Together, Afghanistan and Iraq received 43\% of the democracy assistance budget in 2004, and 26\% in 2005 (Seligson et al. 2008, 155).

In Afghanistan, the resources for reconstruction that financed true political engineering (with projects ranging from the restoration of political institutions to those of the judiciary and public security) stand out on the basis of "democratic principles" shared by the group of donors gathered in the Bonn process begun in 2001. The Iraqi case is even more complex, since it comprehended a unilateral military expedition financed almost exclusively by American citizens' taxes. The whole process began with the underlying justification for regime change, an agenda advocated for some time by neoconservatives who gained momentum with the Bush Doctrine. In addition to objective components - the alleged Iraqi possession of weapons of mass destruction and the connection of Saddam Hussein's government with terrorist groups (namely Al Qaeda) - the 2003 intervention was rhetorically framed as an American mission to foster "freedom and democracy" globally.

In his Second Inaugural Address, George W. Bush clearly put the defense of freedom in line with U.S. values and the strategic requirement to combating terrorism: "The concerted effort of free nations to promote democracy is a prelude to our enemies' defeat" (Bush 2005). Another argument for exporting democracy at gunpoint is that it could mobilize a larger wave of regime changes in rogue states worldwide. In a speech to the American Enterprise Institute, the republican president stated: "A new regime in Iraq would serve as a dramatic and inspiring example of freedom for other nations in the region [...] Success in Iraq could also begin a new stage for Middle Eastern peace” (Office of the Press Secretary 2003).

For Smith, the wars in Afghanistan and Iraq put democracy promotion into question, with its "hyper-Wilsonian militant commitment to fostering nation and state-building" and helped to fuel the crisis of liberal internationalism in American foreign policy (2012, 364). The Bush Doctrine's intimate link between military interventions and the defense of the democratic agenda, as well as the notorious contradiction exposed by the War on Terror's human rights violations (best symbolized by Guantánamo and Abu Ghraib) resulted in an initial withdrawal of Barack Obama's foreign policy from democracy promotion endorsement. Later, Obama rebuilt a rhetorical approach in defense of democracy as a principle, associated with the broader agenda based on human rights and leadership by example. According to his first National Security Strategy: “America's commitment to democracy, human rights, and the rule of law are essential sources of our strength and influence in the world" (President of United States 2010).

The attempt to re-found American foreign policy, moving away from W. Bush's legacy, was materialized with a discreet resumption of assistance for democracy. According to Santos and Teixeira (2015), Obama preferred a "leading from behind" strategy, in which democratization should be a task of nationals, abandoning regime change as a foreign policy option. That was mainly based on multilateral channels (renewing, for example, support for the Community of Democracies network), on the relief of acute democratic crises (as in Haiti, South Sudan, and Côte d'Ivoire), and on open support for rising democracies (Carothers 2012, 18). During the Obama administration, democracy support was not necessarily linked to national security, but 
with broad objectives of supporting global development, coming under the heading of "support for democratic governance" clearly defined by the USAID strategic guideline of 2013 "Strategy on Democracy, Human Rights and Governance."

However, Obama did not escape new contradictions, as his foreign policy was also marked by turmoil in the Middle East after the Arab Spring, with a hesitant response from Washington, and the support for external intervention in Libya (held by NATO forces in 2011) justified under the premise of responsibility to protect. The latter could also be considered inconsistent with Obama's administration criticism of regime change and the "promotion of democracy with bayonets." The challenge posed by the Islamic State was also addressed by alliances with conservative Arab states in the region, similar to general diplomatic rapprochement with governments perceived as undemocratic, like China, Russia, Iran or Cuba (Carothers 2012, 10). Obama's pragmatic foreign policy determined a "selective liberal" approach to democracy promotion (Smith 2012, 378).

The main external shocks that changed U.S. foreign policy strategy also redirected foreign aid priorities from the end of the Cold War to 9/11 (Fleck and Kilby 2010). As described above, the same transformations delimited new priorities to democracy assistance and a growing commitment in terms of budgetary levels, combining an ideational commitment to democratic rule and human rights, with political and security interests in American foreign policy, at least until Donald Trump's election in 2016. His administration has generated widespread concern about proposed cuts to foreign aid in general, and to supporting democracy in particular.

The last budget request sent by Trump's White House to Congress (for the 2020 fiscal year), called for a 50\% reduction in funds for democracy and governance assistance, a deeper cut than the 30\% proposed in 2019. For the 2021 fiscal year, the executive budget proposal would reduce foreign aid funds by $22 \%$. Criticism grew from both sides of the aisle in Washington D.C. (Morello 2020). For congressman Eliot L. Engel (D-NY), chairman of the House Foreign Affairs Committee: "If this draconian budget were enacted, it would weaken our security and leadership around the world [...] Congress will again reject this proposal in resounding bipartisan fashion" ("Engel blasts Trump proposal to slash diplomacy and development budget." 2020).

Foreign aid dismissal can be interpreted as a result of the nationalism and anti-globalism profile summarized by Trump's “America First” motto, along with criticism and cuts in financial contribution to international organizations, protectionist commercial policy and other challenges posed to liberal internationalism. Even during his campaign, Trump mentioned that the U.S. should "stop sending aid to countries that hate us." Secretary of State Mike Pompeo and other high-level officials have also stressed the need to be more selective in sending American aid-dollars abroad, removing support for countries that challenge national interests. More emphasis was given to the private (specifically commercial) aspects of foreign aid agenda, giving birth to the U.S. International Development Finance Corporation in 2019.

Even further, Diamond points out that Trump's overt appreciation for undemocratic leaderships in Russia, Turkey and Saudi Arabia gives a "dangerous sense of license among dictators worldwide" (Diamond 2019). For him, the current presidency marks a rupture with American tradition of 
both republican and democrat presidents for half a century, in support for democratic principles and values (Igoe 2019). Carothers even describes the recent movement as "the rise and fall of U.S. leadership" in democracy promotion, indicating that the vacuum created by American disengagement will be filled by other traditional donors, such as the European Union. Bilaterally, he highlights the growing influence of European donors, mainly Germany, the United Kingdom, Sweden and Norway, in addition to Canada and Australia, and the leaders in South-South Cooperation, such as Brazil, India, and South Africa (Carothers 2019).

The consequences of Trump's attacks on foreign aid were not even more severe thanks to the resilience of foreign aid bureaucracy and its advocates in the State Department and USAID. Another factor of resistance was the continued support from Congress. From 2018 to 2020, congressmen approved historically compatible levels of foreign aid and democracy promotion, in a bi-partisan commitment to reject the one-third cut in resources suggested by Trump. This is especially relevant in face of the declining popular support for democracy promotion, from $24 \%$ in 1993 , to $17 \%$ in 2018. The trend includes a growing gap in political party identification since the 1990s, as there is nowadays more appreciation for democracy promotion from democrats (around 22\%) than from republicans (11\%), according to Pew Research Center's survey ("Conflicting partisan priorities for US foreign policy." 2018). Foreign aid support, as a foreign policy subset, seems to echo the current political polarization in America.

In sum, Trump's push for lower aid levels, along with open hostility towards multilateral fora, may deepen the corrosion of U.S. leadership and, ultimately, the international liberal order. It represents a rupture with American foreign policy confidence in democracy to facilitate cooperation, present from Wilson to Obama, and even further liberal internationalism itself. It also best represents the current crisis in liberal democracy consolidation and expansion, led by "resurgent nationalist, populist and xenophobic movements" and the rise of illiberal powers, such as China and Russia (Ikenberry 2018, 18). To Diamond, the challenge is not only to recapture democracy promotion, but to regain respect and "faith in the American model" $(2019,20)$.

\section{Institutional architecture of democracy assistance: who, how and how much?}

Having reviewed the main historical landmarks of contemporary U.S. democracy assistance, it is important to understand how this agenda is defined and organized, in terms of resources, priorities, bureaucracies and modalities of aid involved. Broadly speaking, democracy assistance can be defined as "a sub-type of foreign aid consisting of targeted aid packages allocated to civil society organizations and political institutions such as legislatures, courts, and political parties designed to empower individuals, groups, and institutions within the recipient state" (Peterson and Scott 2017, 2).

For critics, democratic transitions are often treated by officials "as technocratic exercises" with progress measured according to a "checklist" of democratic attributes, in accordance with the U.S. liberal model. The definitions of democracy and democratization underlying aid programs 
are not fixed, and have only a few core elements, such as prerogatives of free and fair elections and support for fundamental civil rights. Already in 1961, the Foreign Assistance Act mentions the principles of "democratic participation" and "effective institutions of democratic governance" (Lawson and Epstein 2019, 3). Updates have added several amendments (giving rise to new accounts and modalities of democracy assistance) and the appropriation bills themselves which, together with the definition of the federal budget, sometimes earmark spending. In proportion to total U.S. foreign aid, democracy assistance grew from 1,9\% during the Cold War (1975-89) to $12,8 \%$ in post-Cold War (1990-2001). Since 2002, in the post-9/11 phase, it comprised 13,9\% of total foreign aid (Scott and Carter 2015, 10). The rising pattern is even more significant in the 1990s, when general American foreign aid levels were actually falling.

In fifteen years, USAID's budget to the democracy and governance sector expanded ten times, from US\$100 million in 1990 to more than US\$1 billion in 2005, becoming the third-largest category funded by the agency (Seligson et al. 2008, 152). The authors point out that USAID's democracy and governance programs were conducted globally, from Latin America (which received 20\% from 1990-2005) to Eurasia, Europe, Middle East and Africa (16\% each) and Asia (which received a slightly smaller portion of $12 \%$ ). In the period, the most salient change occurred with Latin American levels - that dropped from a 72\% share of U.S. democracy assistance in 1990, growing by only 70\%, while the global increase rate was 604\% (Seligson et al. 2008, 154).

Official data from the U.S. Department of State show the variation in democracy assistance budgetary levels for the last decades. According to Congressional Research Service (Lawson and Epstein 2019, 15), more than seventy countries were contemplated with "Democracy, Human Rights, and Governance" funds in 2017, even if resources were concentrated in a few recipients and regional offices: Afghanistan (US\$ 302 million), Western Hemisphere Regional Office (US\$ 235 million), Syria (US\$ 161 million), Ukraine (US\$ 100 million), Mexico (US\$ 77 million), Colombia and Iraq (each with US\$ 66 million), and Jordan (US\$ 63 million).

\section{Figure 1. Appropriated Funds for Democracy, Human Rights and Governance (in US\$ billions)}

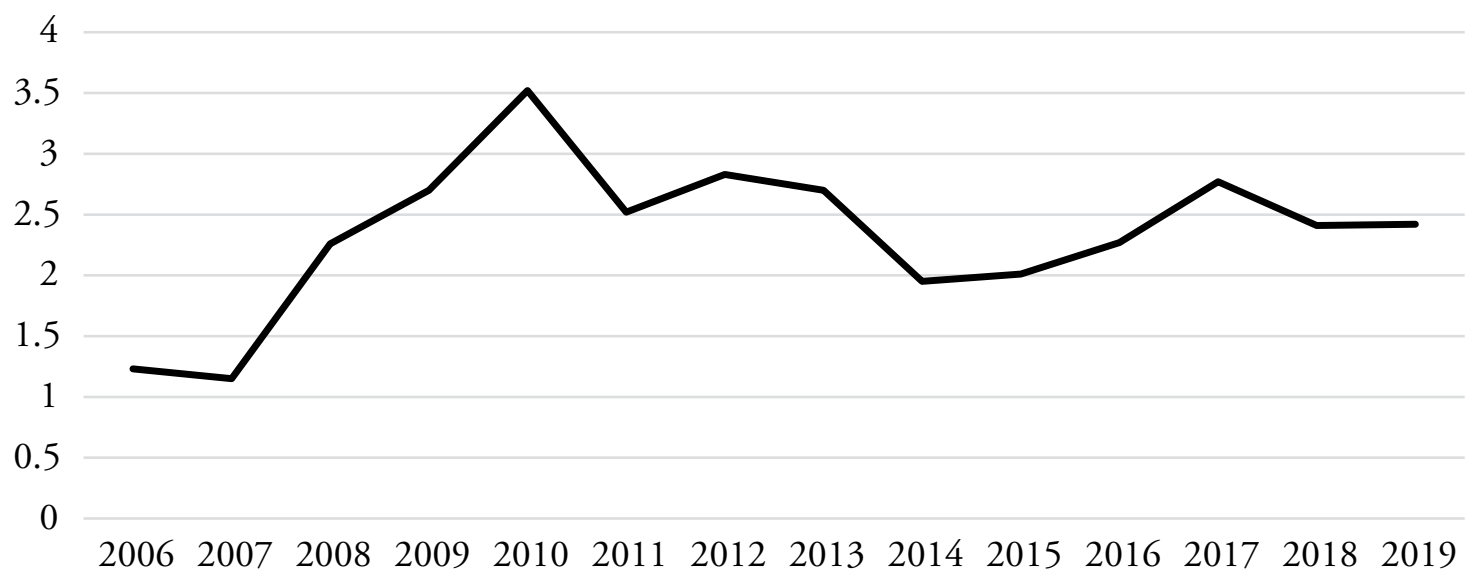


Since 2006, the Governing Justly and Democratically (GJD) strategic objective summarizes American democracy assistance as the advance of democratic values, fundamental freedoms and human rights, the consolidation of democratic institutions and processes (i.e., political competition and fair elections), government accountability and the rule of law, and free ground for civil society and media activities (Lawson and Epstein 2019, 1).

The average level of approved resources under the GJD umbrella is US\$ 2 billion annually, spread across dozens of accounts and mostly administered by the State Department and USAID. Contrary to general supposition, U.S. democracy assistance is not concentrated in "election financing" or direct party involvement. In the 2015 budget, the last consolidated expenses, resources destined to support political competition was less than $8 \%$, while support for good governance was 35\%, and rule of law and human rights 32\%, with 25\% in aid for civil society (Lawson and Epstein 2019, 14).

Table 1. Democracy Assistance Funding by Subcategory (in US\$ millions)

\begin{tabular}{lcccccccccccc}
\hline & $\mathbf{2 0 0 6}$ & $\mathbf{2 0 0 7}$ & $\mathbf{2 0 0 8}$ & $\mathbf{2 0 0 9}$ & $\mathbf{2 0 1 0}$ & $\mathbf{2 0 1 1}$ & $\mathbf{2 0 1 2}$ & $\mathbf{2 0 1 3}$ & $\mathbf{2 0 1 4}$ & $\mathbf{2 0 1 5}$ & $\mathbf{2 0 1 6}$ & $\mathbf{2 0 1 7}$ \\
\hline $\begin{array}{l}\text { Rule of Law - } \\
\text { Human Rights }\end{array}$ & 437 & 532 & 608 & 699 & 888 & 758 & 940 & 1017 & 636 & 659 & 794 & 829 \\
$\begin{array}{l}\text { Good } \\
\text { Governance }\end{array}$ & 638 & 763 & 762 & 1088 & 1518 & 974 & 1037 & 942 & 690 & 716 & 886 & 1014 \\
$\begin{array}{l}\text { Political } \\
\text { Competition }\end{array}$ & 203 & 305 & 295 & 433 & 321 & 231 & 247 & 226 & 168 & 163 & 164 & 221 \\
$\begin{array}{l}\text { Civil } \\
\text { Society }\end{array}$ & 480 & 541 & 593 & 482 & 543 & 544 & 603 & 516 & 458 & 396 & 429 & 705 \\
$\begin{array}{l}\text { GJD } \\
\text { Total }\end{array}$ & 1758 & 2141 & 2259 & 2702 & 3269 & 2517 & 2826 & 2701 & 1952 & 1934 & 2273 & 2769 \\
\hline
\end{tabular}

Source: Elaborated by the author based on Lawson and Epstein 2019, 14-15

Historically, the distribution of democracy aid by subcategory varied from region to region, with a predominance of assistance toward civil society to Eastern Europe and Eurasia, governance programs to the Middle East, and strengthening of the rule of law in Latin America. The distribution of democracy assistance according to regional priorities challenges the common criticism that Washington government sets a "one-size-fits-all” model in foreign aid (Seligson et al. 2008, 156).

Another element not captured when we look exclusively at the GJD accounts is democratic aid channeled multilaterally. The U.S. contributes to a number of international organizations that promote democracy as a development goal, such as the Organization of American States, the Organization for Security and Co-operation in Europe, the World Bank and the United Nations Development Programme. In the field of informal multilateral initiatives, we have several cooperation networks between states and non-state actors, with emphasis on the World Movement for Democracy. The complexity between bilateral and multilateral aid instruments is maximized by the maze of democracy promotion implementation composed by bureaucracies in the American government and private actors (non-profit and for-profit contractors in development assistance). 
Within the governmental architecture of foreign aid, there are a number of actors, accounts and programs. Between 95-99\% of democracy assistance funding is channeled through USAID, which in the 1990s created offices for "Democracy and Governance" and "Transition Initiatives" - both allocated to the Bureau of Democracy, Conflict and Humanitarian Assistance, and moving approximately US\$1.3 billion annually (Melia 2005, 5). In 2012, the Center for excellence on Democracy, Human Rights and Governance was created and today operates in dozens of countries worldwide.

It is also noteworthy that USAID itself works in partnership with non-governmental actors to implement cooperation projects. Thus, a series of private actors (mainly American-based) end up mediating the agency's democratic aid. USAID establishes four types of resources (contracts, cooperative agreements, direct grants or via international organizations) that differentiate those who operate on the ground - USAID itself, local partners or in the form of granting resources involving third parties (US Government Accountability Office 2017, 56).

Another auxiliary mechanism celebrated as an important pillar of democratic governance is the Millennium Challenge Corporation (MCC), created in 2004 during George W. Bush's administration. The agency does not promote democracy per se, but does apply a rigid mechanism of selectivity through indicators for project eligibility, including civil liberties and political rights. Thus, only countries that already have good indicators of democratic governance and respect for human rights can receive resources from the MCC, which also provides technical support for countries that are in the so-called threshold programs (and still need to improve their performance to become eligible for compacts).

The State Department, on the other hand, is in charge of day-to-day bilateral diplomatic relations through embassies, working as a thermometer to evaluate the democratic qualities of American partners. In the Bureau of Democracy, Human Rights and Labor Affairs, the State Department has a space dedicated to democratization, in addition to funding local and international NGOs involved in promoting democracy and human rights, such as the Human Rights and Democracy Fund. The position of Coordinator for Reconstruction and Stabilization was created in 2004, mainly to deal with the reconstructions of Iraq and Afghanistan, being therefore responsible for institutional building and democratic governance issues. The State Department also runs educational and justice cooperation projects, both sensitive to the democracy agenda. Other instances of the executive branch also contribute to U.S. democratic aid, such as the Department of Justice, active in programs directed at the rule of law and the administration of justice, and the Department of Defense through police and military training programs.

Despite concentrated efforts on the executive, most programs are in fact implemented by the private sector, through non-profit and for-profit organizations. One example is the National Endowment for Democracy (NED) which, despite being funded by the State Department, works as a grant source for NGOs such as the National Democratic Institute (NDI) and the International Republican Institute (IRI). These are respectively linked to the Democratic and Republican parties, in addition to the Center for International Private Enterprise and Solidarity Center, among other 
organizations inside and outside the United States. Resources allocated to NED are not computed by the GJD, but are understood as an integral component of American democracy promotion, having comprised an average of 5\% of its annual budget since 2002 .

Thus, NED works through diffuse channels with broad involvement of the civil society (civic organizations, business associations, churches, press vehicles and universities) in the countries where it operates: "Through these institutes, the U.S. government and business corporations can, in some way, exercise influence over public policies and supporting different organizations and political forces in many countries" (Barbosa 2019, 89-90). The author, who specifically examined NED's work in Ecuador, highlights its ability to disseminate American values and principles through its operation as a transnational network. As a non-governmental organization, NED is able to advance American democracy aid in so-called "restrictive environments" where the presence of USAID or the State Department is not welcome, as evidenced by the list of NED's top recipients: China, Burma, Russia, Ukraine and Cuba (Lawson and Epstein 2019, 16).

In the public-private arrangements for democracy promotion, the best-known non-profit and for-profit organizations operating as government contractors in democracy promotion are the International Foundation for Electoral Systems (IFES), the Research Triangle Institute (RTI), the Management Systems International (MSI), Chemonics, Development Associates, Development Alternatives. The democracy promotion game also includes research centers and think tanks such as the Carnegie Endowment for International Peace, the Carter Center, the Hoover Institution, Freedom House, the Journal of Democracy (supported by NED's International Forum for Democratic Studies), the U.S. Institute for Peace, the Center for American Progress, to name just a few within a wide scope in the U.S. political-ideological spectrum (Melia 2005, 5).

One of the paradoxes presented by Mitchell (2016) is precisely the role of American civil society organizations financed by the government - not only IRI and NDI, financed by the State Department through NED, but also the Freedom House, largely financed by USAID. The same is true for local NGOs, which are indirectly financed by Washington, and have their impartiality and independence questioned. It may be asked, therefore, to what extent U.S. foreign aid actively and diffusely connected to civil society networks end up being an instrument of intervention, forming leaders and changing the power game in favor of Washington's interests in several countries around the world.

Obviously, like any other foreign policy agenda, decision making in democracy assistance has been influenced both by external events and by internal pressures from domestic priorities and interest groups, particularly through lobbies, echoing a classic tension in foreign aid practice, between the demands of recipients and the interests of donors, in which the latter almost always prevail. Bridoux points out that contemporary U.S. democracy assistance allocation is conditioned by three pressure points: domestic politico-economic conditions, strategic interests, and international ideological challenges to the U.S. liberal model of market democracy $(2013,235)$. It is coherent to Alesina and Dollar's classic study demonstrating that from the 1970s through the mid-90s, the main determinants of foreign aid allocation are indeed strategic considerations, such as political 
alliances (voting patterns in the UN), strategic and regional interests. They also find that general aid levels tend to increase in face of positive changes in democracy (on average 50\%) - in a sense "rewarding countries that democratize" (Alesina and Dollar 2000, 50).

Other than strategic political incentives, it is also important to consider the "potential for success" that guides overall rationale in foreign aid decision making and allocation processes. For this reason, the effectiveness concern and results-based "project culture" often surpasses immediate donor's interests or recipients' demands, casting "democracy aid allocations as strategic bets placed by aid allocators on recipients more likely to show progress toward and consolidation of democracy" (Scott and Carter 2019,3). In this sense, the authors verified that historically, more democracy aid has been directed to multiparty authoritarian regimes with "feasibility of democracy" - where civil society support may increase the chance of successful transition and regime consolidation, in a rational investment logic.

The distributive patterns in American democracy assistance analyzed by Scott and Carter point to a combination of interests and ideational motivations, in a three-period profile. During the Cold War, democracy aid allocation responded to interest-based concerns, mainly political alliances and security, directed at consolidated democratic regimes with good human rights performance. During the post-Cold War period, ideational concerns prevailed (with democracy and human rights promoted as an end in itself), as well as democracy aid directed to countries in the process of consolidation of democracy with problematic human rights performances and possibly emerging from conflict. Following the 2001 terrorist attacks, U.S. democracy aid combined both because, even if security guided a major part of the allocation process, human rights and democracy promotion were still secondary factors (Scott and Carter 2017, 32). In face of the historical retrospect listed in early sections, it is interesting to note that ideational concerns helped to cement the rhetorical justification to democracy aid, while security and political interests mainly guided the actual aid allocation.

\section{Conclusion}

U.S. democracy promotion has long been used as a foreign policy objective and a backdrop to justify various forms of interference (including military interventions to change regimes), as well as an instrument for American interests abroad, building, in Washington's mindset, a more "peaceful and prosperous" international order. As discussed, this framing was already present in the first international engagements by the newly independent country, and from the bipolar moment to the present. Always connected to the issues of free trade, human rights and national security, the promotion of democracy appears prominently in all administrations, whether republican- or democrat-led. Today, the elements of institutional capacity, good governance and the guarantee of basic freedoms figure centrally in American foreign policy, at an interface between aid-development and security agendas that involve multi-dimensional capacity (re)building programs essential for understanding U.S. international affairs. 
Democracy promotion is composed today mainly of projects administrated by USAID, but involves other federal bureaucracies, such as the State, Defense and Treasury departments, and specialized agencies like the MCC. It also comprises a decentralized and hybrid implementing architecture, through for-profit and non-profit organizations, providing "a drip-feed" to transnational networks of local actors in activities as diverse as funding interest groups (unions or party associations), press vehicles (radio and newspapers), institutional reforms (in the legislative and judicial fields, for example) and even training of public security forces. There is no operational center that delimits clear conceptions of what "good governance" would be, or even what is a healthy "democracy." Nor is there, even within the scope of the U.S. executive branch, a coordination mechanism among the various bureaucracies involved and among its network of contractors.

As we have seen, it is not that easy to keep track of the amounts spent by Washington on democracy promotion, and even harder to measure democracy aid effectiveness, although consolidated bureaucracies, mainly USAID, have recently sought to develop quantifiable metrics to ascertain effectiveness and establish accountability mechanisms. In light of the complexity in the spread of resources mediated by multiple actors, it is especially important to apply the "follow the money" strategy and to assess the program's impacts on the ground.

From the very beginning, the construction of the U.S. hegemonic order relied on democratic norm as a central element for the liberal order architecture forged in the twentieth century. Thus, the sense of mission established by American exceptionalism (as the guarantor of freedom in the world) fit well with Washington's strategic interests, in economic, political or security terms, in the most diverse phases of American foreign policy - whether in bipolarity, unipolarity, or the global war on terrorism.

The enlargement of the global democratic community has played an important role on U.S. strategy, historically projecting power and consent through multilateral institutions. Low intensity democracy also became a source of legitimacy and stability abroad, deflecting popular pressure for structural reforms and guaranteeing the interests of transnational capitalist elites. The "battle for global civil society" in constructing a circuit of democracies through multi-channeled foreign assistance showed great value for the American order. That may be the reason why, although Trump's administration recently questioned the validity of democracy aid, there is widespread resistance from domestic actors (mainly in Capitol Hill and Foggy Bottom officials) to keep the democracy agenda alive.

\section{References}

Alesina, A., and D. Dollar. "Who gives foreign aid to whom and why?" Journal of Economic Growth 5, no. 1 (2000): 33-63. doi: https://doi.org/10.1023/A:1009874203400 Allison, G., and R. Beschel. "Can the United States promote democracy?” Political Science Quarterly 107, no. 1 (1992): 81-98. doi: https://doi.org/10.2307/2152135 
Barbosa, L. C. B. "A assistência externa de promoção da democracia liberal dos Estados Unidos na América Latina.” Carta Internacional 14, no. 3 (2019): 4-109. doi: https://doi.org/10.21530/ ci.v14n3.2019.947

Bridoux, J. "US foreign policy and democracy promotion: in search of purpose." International Relations 27, no. 2 (2013): 235-240. doi: https://doi.org/10.1177/0047117813489655b

Brown, S., and J. Gravingholt. The securitization of foreign aid. New York, NY: Palgrave MacMillan, 2016.

Bush, G. W. "President Bush's second inaugural address." National Public Radio, January 20, 2005. https://www.n pr.org/templates/story/story.php? storyId $=4460172$

Carothers, T. Democracy policy under Obama: revitalization or retreat? Washington, DC: Carnegie Endowment for International Peace, 2012.

Carothers, T. International democracy support: filling the leadership vacuum. Washington, DC: Carnegie Endowment for International Peace, 2019.

"Conflicting partisan priorities for US foreign policy." Pew Research Center, November 29, 2018. https://www.people-press.org/2018/11/29/conflicting-partisan-priorities-for-u-s-foreignpolicy/

Cox, M. G., J. Ikenberry, and T. Inoguchi. (eds.). American democracy promotion: impulses, strategies, and impacts. New York, NY: Oxford University, 2000.

Diamond, L. "Democracy demotion: how the freedom agenda fell apart." Foreign Affairs 98, no. 4 (2019): 17-25.

Doyle, M. W. "Liberalism and world politics." American Political Science Review 80, no. 4 (1986): 1151-1169. doi: https://doi.org/10.1017/S0003055400185041

"Engel blasts Trump proposal to slash diplomacy and development budget." House of Representatives Committee on Foreign Affairs Press Release, February 10, 2020. https://foreignaffairs.house. gov/2020/2/engel-blasts-trump-proposal-to-slash-diplomacy-and-development-budget

Fleck, R. K., and C. Kilby. "Changing aid regimes? US foreign aid from the cold war to the war on terror." Journal of Development Economics 91, no. 2 (2010): 185-197. doi: https:// doi.org/10.1016/j.jdeveco.2009.09.011

Gomes, A. T. "Democracia como significante vazio: promoção democrática na política externa dos Estados Unidos (2001-2008)." Revista Brasileira de Ciências Sociais 31, no. 92 (2016): 1-18. doi: https://doi.org/10.17666/319214/2016

Huber, D. Democracy promotion and foreign policy: identity and interests in US, EU and non-Western democracies. London: Palgrave Macmillan, 2015.

Huntington, S. “Democracy's third wave.” Journal of Democracy 2, no. 2 (1991): 12-34.

Igoe, M. "Can US democracy promotion survive Donald Trump?” Devex, November 6, 2019. Ikenberry, G. J. Liberal Leviathan: the origins, crisis, and transformation of the american world order. Princeton, NJ: Princeton University, 2011.

Ikenberry, G. J. “The end of liberal international order?” International Affairs 94, no. 1 (2018): 7-23. doi: https://doi.org/10.1093/ia/iix241 
Lancaster, C. Foreign aid: diplomacy, development, domestic politics. Chicago, IL: The University of Chicago, 2007.

Lawson, M. L., and S. B. Epstein. "Democracy promotion: an objective of U.S. foreign assistance." Congressional Research Service, January 4, 2019.

Mateo, L. R. A ajuda externa e a formulação da estratégia internacional dos Estados Unidos a partir do 11 de setembro de 2001. Doctor Thesis. Universidade Estadual Paulista, São Paulo, SP, Brasil, 2017.

Melia, T. O. The democracy bureaucracy: the infrastructure of american democracy promotion. Discussion paper. Princeton, NJ: Princeton Project on National Security, 2005.

Mitchell, L. A. The democracy promotion paradox. Washington, DC: Brookings Institution, 2016.

Morello, C. "Trump administration again proposes slashing foreign aid." Washington Post, February 10, 2020. https://www.washingtonpost.com/national-security/trumpadministration-again-proposes-slashing-foreign-aid/2020/02/10/2c03af38-4c4c-11 eabf44-f5043eb3918a_story.html

National Security Strategy - NSS. National security strategy for a new century. Washington, DC: White House, 1997. https://history.defense.gov/Portals/70/Documents/nss/ nss 1997.pdf?ver=2014-06-25-121242-623

Office of the Press Secretary. President discusses the future of iraq. Washington, DC: White House, 2003. https://georgewbush-whitehouse.archives.gov/news/ releases/2003/02/20030226-11.html

President of United States. National security strategy. Washington, DC: White House, 2010. https:// obamawhitehouse.archives.gov/sites/default/files/rss_viewer/national_security_strategy.pdf

Pee, R. "Containing revolution: democracy promotion, the cold war and US national security." International Politics 55, no. 1 (2018): 693-711. doi: https://doi.org/10.1057/s41311-0170094-0

Peterson, T. M., and M. J. Scott. "The democracy aid calculus: regimes, political opponents, and the allocation of US democracy assistance, 1981-2009.” International Interactions 44, no. 2 (2017): 268-293. doi: https://doi.org/10.1080/03050629.2017.1339701

Poppe, A. E. "Whither to, Obama? US democracy promotion after the cold war." PRIF Reports n. 96, 2010.

Robinson, W. I. "Promoting capitalist polyarchy: the case of Latin America." In American democracy promotion: impulses, strategies, and impacts, edited by M. G. Cox, J. Ikenberry, and T. Inoguchi. New York, NY: Oxford University, 2000.

Robinson, W. I. "Promoting polyarchy: 20 years later." International Relations 27, no. 2 (2013): 228-234. doi: https://doi.org/10.1177/0047117813489655a

Santos, M. H. C. "Exportação de democracia na política externa norte-americana no pós-GuerraFria: doutrinas e o uso da força.” Revista Brasileira de Politica Internacional 53, no. 1 (2010): 158-191. doi: https://doi.org/10.1590/S0034-73292010000100009 
Santos, M. H. C., and U. T. Teixeira. “Interests and values in Obama’s foreign policy: leading from behind?" Revista Brasileira de Politica Internacional 58, no. 2 (2015): 119-145. doi: https://doi.org/10.1590/0034-7329201500207

Scott, J. M., and R. G. Carter. "Promoting democracy in Latin America: foreign policy change and US democracy assistance, 1975-2010." Third World Quarterly 37, no. 2 (2015): 299-320. doi: https://doi.org/10.1080/01436597.2015.1108824

Scott, J. M., and R. G. Carter. "Distributing dollars for democracy: changing foreign policy contexts and the shifting determinants of US democracy aid, 1975-2010." Journal of International Relations and Development 22, no. 2 (2017): 640-675. doi: https://doi. org/10.1057/s41268-017-0118-9

Scott, J. M., and R. G. Carter. "Democratizing dictators? Non-democratic regime conditions and the allocation of US democracy assistance, 1975-2010." International Political Science Review 41, no. 3 (2019): 436-450. doi: https://doi.org/10.1177/0192512119858358

Seligson, M. A., D. Azpuru, S. E. Finkel, and A. Pérez-Liñán. "Trends in democracy assistance: what has the United States been doing?" Journal of Democracy 19, n. 2 (2008): 150-159. doi: https://doi.org/10.1353/jod.2008.0035

Smith, T. America's mission: the United States and the worldwide struggle for democracy in the twentieth century. Princeton, NJ: Princeton University, 2012.

US Government Accountability Office - GAO. “Democracy assistance: state should improve accountability over funding; Usaid should assess whether new processes have improved award documentation.” GAO 18-136, December 14, 2017. https:/www.gao.gov/products/ GAO-18-136 